\title{
EDINBURGH JOURNAL OF BOTANY
}

AN INTERNATIONAL JOURNAL OF PLANT SYSTEMATICS AND BIODIVERSITY

Volume 74, No. 1

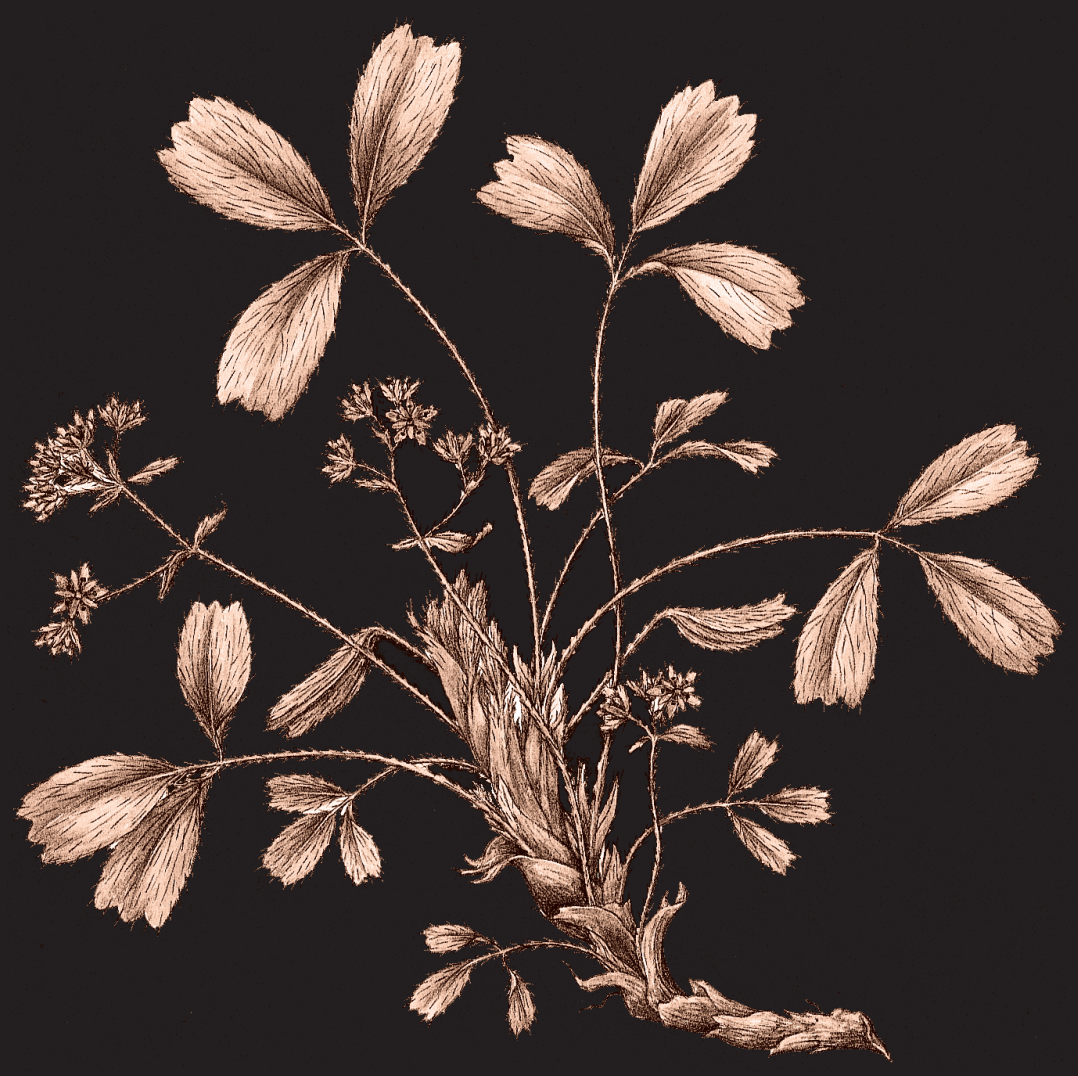




\section{EDITORIAL BOARD}

Dr Mark Newman, Editor-in-chief Royal Botanic Garden Edinburgh Taxonomy - Southeast Asia

Dr Domingos Cardoso, Associate Editor Universidade Estadual de Feira de Santana Phylogenetics

Mr Martin Gardner, Associate Editor Royal Botanic Garden Edinburgh Conservation and biodiversity surveys

Dr David Harris, Associate Editor Royal Botanic Garden Edinburgh Taxonomy - Africa

Dr Elspeth Haston, Associate Editor Royal Botanic Garden Edinburgh Bioinformatics and taxonomic theory

Dr Mark Hughes, Associate Editor Royal Botanic Garden Edinburgh Book reviews

Dr Sabina Knees, Associate Editor Royal Botanic Garden Edinburgh Taxonomy - Europe and the Middle East
Dr Michael Möller, Associate Editor

Royal Botanic Garden Edinburgh

Taxonomy - China

Dr Ary Oliveira Filho, Associate Editor Universidade Federal de Minas Gerais Ecology

Dr James Richardson, Associate Editor Royal Botanic Garden Edinburgh

Biogeography

Dr Tiina Särkinen, Associate Editor Royal Botanic Garden Edinburgh Taxonomy - New World

Dr Mark Watson, Associate Editor Royal Botanic Garden Edinburgh Taxonomy - India and the Himalayas

Dr Rebecca Yahr, Associate Editor

Royal Botanic Garden Edinburgh

Cryptogams

Copy-editor: Dr Kim Howell

For Editorial Advisory Board see the journal website at journals.cambridge.org/ejb

\section{SUBSCRIPTIONS}

Edinburgh Journal of Botany (ISSN 0960-4286) is published three times a year in March, July and November. Three parts form a volume. The subscription price of volume 74 (which includes electronic access and postage, but excludes VAT) is $£ 309.00$ (US $\$ 579.00$ in the USA, Canada and Mexico). The electronic-only price available to institutional subscribers is $£ 235.00$ (US $\$ 437.00$ in the USA, Canada and Mexico). Single parts are $£ 112.00$ net (US \$209.00 in the USA, Canada and Mexico) plus postage. EU subscribers (outside the UK) who are not registered for VAT should add VAT at their country's rate. VAT registered subscribers should provide their VAT registration number. Japanese prices for institutions are available from Kinokuniya Company Ltd, P.O. Box 55, Chitose, Tokyo 156, Japan. Prices include delivery by air. Orders, which must be accompanied by payment, may be sent to a bookseller, subscription agent or direct to the publisher: Cambridge University Press, UPH, Shaftesbury Road, Cambridge CB2 8BS, UK; or in the USA, Canada and Mexico: Cambridge University Press, 1 Liberty Plaza, Floor 20, New York, NY 10006, USA. Copies of the journal for subscribers in the USA, Canada and Mexico are sent by air to New York to arrive with minimum delay.

\section{COPYING}

The Journal is registered with the Copyright Clearance Center, 222 Rosewood Drive, Danvers, MA 01923, USA. Organisations in the USA who are also registered with C.C.C. may therefore copy material (beyond the limits permitted by sections 107 and 108 of U.S. Copyright law) subject to payment to C.C.C. of the per-copy fee of $\$ 16.00$. This consent does not extend to multiple copying for promotional or commercial purposes. Code 0960-4286/2017/\$16.00.

ISI Tear Sheet Service, 3501 Market Street, Philadelphia, Pennsylvania 19104, USA, is authorised to supply single copies of separate articles for private use only.

Organisations authorised by the Copyright Licensing Agency may also copy material subject to the usual conditions.

For all other use of material from the Journal permission should be sought from Cambridge or from the American Branch of Cambridge University Press.

Information on Edinburgh Journal of Botany and all other Cambridge journals can be accessed via http://www.cambridge.org/.

Disclaimer: The views expressed in Edinburgh Journal of Botany do not necessarily reflect those of the Editorial Board or of the Royal Botanic Garden Edinburgh. 